\title{
Analysis of Water Quality in Urban Water Supply System of Bangladesh
}

\author{
Tapos Kormoker*, Ram Proshad and Mohammad Mahmud Khan
}

Patuakhali Science and Technology University, Bangladesh

\begin{abstract}
Supply of safe drinking-water is world-wide considered to be an important issue for public health safety and must be the key objective of water supply systems. The aim of this research is to analyze the supply water quality in urban water supply system of Bangladesh. This research was conducted in two Pourashava water supply systems namely Barguna Pourashava and Faridpur Pourashava of Bangladesh. Some concerned chemical, biological and physical parameters were tested for an initial assessment of the water quality of the source water. A total of ten ground water based production well's water samples were examined in those two Pourashava. A total of nine samples, one from each ward were collected form the entry point of the supply water to the user's house were analyzed for $E$. coli which represented the quality of the piped water. A total of three water samples were collected from each of the ward for microbiological (FC) quality analysis. Millipore microbiological field testing kits was used for E. coli testing, DR 2800 $\mathrm{HACH}$ spectrophotometer was used for determination of manganese, iron, and nitrate and Wegtech Digital Arsenator was used for arsenic determination. Physical parameters were tested by HACH potable instruments. The light brown yellowish color created an aesthetic problem among the water users of Barguna Pourashava. In addition, the fecal contamination rate was very high. The findings of $E$. coli analysis of Barguna Pourashava supply water indicated that $11 \%$ have intermediate risk, $37 \%$ have high risk and $52 \%$ have very high risk considering the health. The water of the production wells of Faridpur Pourashava has high concentration of the arsenic, iron and E. coli. The household's storage water sample analysis result indicated that $48 \%, 44 \%$ and $7 \%$ have very high risk, high risk and intermediate risk from the health point of view.
\end{abstract}

Keywords: Water quality; Water supply system; Health risks; Contamination; Monitoring; Management; Bangladesh

\section{Introduction}

Water supply and sanitation is characterized by a number of achievements and challenges. Urban water supply system has become a more critical issue in the socio-economic condition of a country. It is very important factor now a days and also it indicates the quality of urban life. Bangladesh is one of the most densely populated country in the world. The country has a population density of $1,115.62$ people per square kilometer, $(2,889.45 /$ square mile), which ranks 10 th in the world. Urban people faced a problem of safe drinking water due to lack of appropriate urban water supply system in Bangladesh. The extent and availability of safe drinking water is an important indicator of sustainable development, and access to clean water constitutes a principal components of the Millennium Development Goals (MDGs). There was an estimation that more than 70 percent of the urban population in the developing countries are either have an inadequate water supply or being supplied with unsafe water or both [1]. Safe water and improved sanitation are powerful determinants of health. The WHO program in Bangladesh aims at promoting preventive approaches to water quality management using Water Safety Plans (WSP) to enable utilities, small communities and the households to ensure safety of drinking water. Since the quality of drinking water is closely associated with human health, providing safe drinking water is one of the most important public health priorities. An estimated 80 percent of all diseases and one third of deaths in developing countries are caused by the consumption of contaminated water [2]. About 25 percent of the total population lives in urban Bangladesh, and only 44 percent of the urban people are served with tap water supply [3]. The lower income group is the worst sufferers as because they cannot afford to have safe drinking water for an active and healthy life $[4,5]$. Present study focus on the water quality analysis in the urban water supply system in Bangladesh with health risk assessment of urban people.

\section{Materials and Methods}

Two Pourashava water supply systems were selected considering the geography namely Faridpur Pourashava of Faridpur District (as flood prone area) and Barguna Pourashava of Barguna District (as coastal area) for conducting this research (Figure 1). The Faridpur Pourashava water supply system has around 7600 users and the Barguna Pourashava have 3800 users. The user list was collected from each of the Pourashava which were proportionally distributed in each ward. Some concerned chemical, biological and physical parameters were tested for an initial assessment of the water quality of the source water. Only one ground water based production well's water was examined at Barguna Pourashava and total of nine production well's water were examined at Faridpur Pourashava. A total of nine samples, one from each ward were collected form the entry point of the supply water to the user's house were analyzed for $E$. coli which represented the quality of the piped water. A total of three water samples were collected from each of the ward for microbiological (FC) quality analysis. The water samples were collected from the nearest water users of the distribution line in any ward, middle and the farthest. A few household's samples were checked for arsenic. The source water was checked for FC, arsenic, iron, manganese occasionally nitrate. Millipore microbiological field testing kits was used for $E$. coli testing, DR $2800 \mathrm{HACH}$ spectrophotometer was used for determination of manganese, iron, and nitrate and Wegtech Digital Arsenator was used for arsenic determination. Some physical parameters were also tested namely $\mathrm{pH}$, turbidity, total dissolved solids, conductivity etc. Physical parameters were tested by $\mathrm{HACH}$ potable instruments. All the testing was conducted in the field. The water quality testing was conducted by the skilled professionals (Table 1).

*Corresponding author: Tapos Kormoker, Patuakhali Science and Technology University, Bangladesh, Tel: +8801759368602; E-mail: tapos.pstu@gmail.com

Received July 10, 2017; Accepted July 15, 2017; Published July 20, 2017

Citation: Kormoker T, Proshad R, Khan MM (2017) Analysis of Water Quality in Urban Water Supply System of Bangladesh. J Environ Anal Toxicol 7: 492. doi: 10.4172/2161-0525.1000492

Copyright: @ 2017 Kormoker T, et al. This is an open-access article distributed under the terms of the Creative Commons Attribution License, which permits unrestricted use, distribution, and reproduction in any medium, provided the original author and source are credited. 
Citation: Kormoker T, Proshad R, Khan MM (2017) Analysis of Water Quality in Urban Water Supply System of Bangladesh. J Environ Anal Toxicol 7: 492. doi: 10.4172/2161-0525.1000492

Page 2 of 5

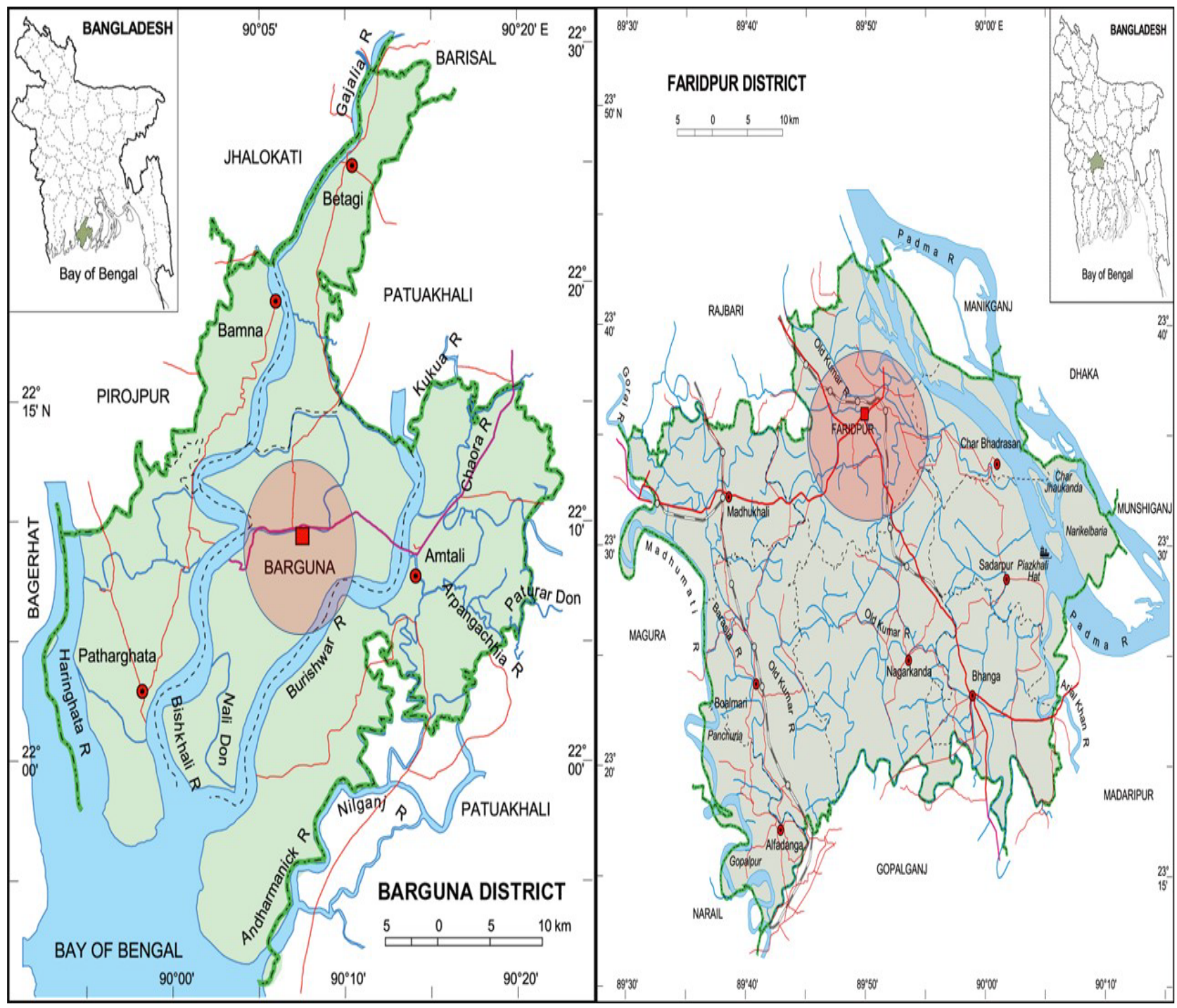

Figure 1: Map showing the sampling sites of Faridpur and Barguna Pourashava of Bangladesh.

\begin{tabular}{|c|c|c|c|}
\hline Water quality parameters & Units & Bangladesh standards \\
\hline Odor & & Odorless \\
\hline $\mathrm{pH}$ & & $6.0-8.5$ \\
\hline Electrical conductivity & $\mu \mathrm{s} / \mathrm{cm}$ & 500 \\
\hline Turbidity & $\mathrm{NTU}$ & 5.0 \\
\hline Arsenic & $\mathrm{mg} / \mathrm{O}$ & 0.05 \\
\hline $\mathrm{Fe}$ & $\mathrm{mg} / \mathrm{l}$ & 0.3 \\
\hline $\mathrm{Mn}$ & $\mathrm{mg} / \mathrm{l}$ & $150-600^{*}$ \\
\hline Nitrate & $\mathrm{mg} / \mathrm{l}$ & $40-50$ \\
\hline E. coli & $/ 100 \mathrm{ml}$ & Absent \\
\hline
\end{tabular}

Table 1: Water quality parameters and standard [5].

\section{Results and Discussion}

\section{Water quality in Barguna Pourashava water supply system}

Only one ground water based production well's water was examined for some concerned chemical, biological and physical parameters as presented in Table 2 for an initial assessment of the water quality of the source water. The light brown yellowish color created an aesthetic problem among the water users and the fecal contamination was too high. 
Citation: Kormoker T, Proshad R, Khan MM (2017) Analysis of Water Quality in Urban Water Supply System of Bangladesh. J Environ Anal Toxicol 7: 492. doi: 10.4172/2161-0525.1000492

Page 3 of 5

\begin{tabular}{|c|c|c|c|}
\hline No & Particulars & Unit & Results \\
\hline 1 & Location & & Tulatoli Pump House \\
\hline 2 & Source Type & & Deep Tube Well \\
\hline 3 & Catchment Area/Depth & $\mathrm{ft}$ & 940 \\
\hline 4 & Color & & Light Yellowish Brown \\
\hline 5 & Odor & & Smell of Rotten Egg \\
\hline 6 & $\mathrm{pH}$ & & 8.16 \\
\hline 7 & ORP & $\mathrm{mV}$ & -155.8 \\
\hline 8 & Electrical conductivity & $\mu \mathrm{s} / \mathrm{cm}$ & 1158 \\
\hline 9 & Salinity & $\mathrm{mg} / \mathrm{l}$ & \\
\hline 10 & LOD & $\mathrm{mg} / \mathrm{l}$ & 2.83 \\
\hline 11 & Turbidity & NTU & 1.1 \\
\hline 12 & As & $\mathrm{mg} / \mathrm{l}$ & 0 \\
\hline 13 & $\mathrm{Fe}$ & $\mathrm{mg} / \mathrm{l}$ & 0.05 \\
\hline 14 & $\mathrm{Mn}$ & $\mathrm{mg} / \mathrm{l}$ & 0.4 \\
\hline 15 & Nitrate & $\mathrm{mg} / \mathrm{l}$ & 8.5 \\
\hline 16 & E. coli & $/ 100 \mathrm{ml}$ & TNTC \\
\hline 17 & Other coli form & $/ 100 \mathrm{ml}$ & TNTC \\
\hline 18 & Total coli form & $/ 100 \mathrm{ml}$ & TNTC \\
\hline
\end{tabular}

TNTC: To numerous to count) in the source water

Table 2: Water quality analysis result of production wells of Barguna Pourashava water supply system.

\begin{tabular}{|c|c|c|c|c|c|}
\hline \multirow{2}{*}{ Ward No } & \multicolumn{5}{|c|}{ Microbial Risk (HH's source water sample) } \\
\hline & Low & Intermediate & High & Very High & Grand Total \\
\hline Ward 1 & & & 1 & & 1 \\
\hline Ward 2 & & & & 1 & 1 \\
\hline Ward 3 & & & & 1 & 1 \\
\hline Ward 4 & & & 1 & & 1 \\
\hline Ward 5 & & 1 & & & 1 \\
\hline Ward 6 & & & 1 & & 1 \\
\hline Ward 7 & & & & 1 & 1 \\
\hline Ward 8 & & & & 1 & 1 \\
\hline Ward 9 & & & 1 & & 1 \\
\hline Grand Total & 0 & 1 & 4 & 4 & 9 \\
\hline
\end{tabular}

Table 3: Microbiological analysis of the household's source water samples of Barguna Pourashava.

\begin{tabular}{|c|c|c|c|}
\hline \multirow{2}{*}{ Ward No } & \multicolumn{3}{|c|}{ Microbial Risk (\% of household's storage water sample) } \\
\cline { 2 - 4 } & Intermediate & High & \multicolumn{2}{|c|}{ Very High } \\
\hline Ward 1 & $33(1)$ & $67(2)$ & $67(2)$ \\
\hline Ward 2 & $33(1)$ & $33(1)$ & $67(2)$ \\
\hline Ward 3 & & & $100(3)$ \\
\hline Ward 4 & & & $100(3)$ \\
\hline Ward 5 & $33(1)$ & $67(2)$ & $33(2)$ \\
\hline Ward 6 & & $67(2)$ & $33(1)$ \\
\hline Ward 7 & & $33(1)$ & $100(3)$ \\
\hline Ward 8 & & $67(2)$ & $100(3)$ \\
\hline Ward 9 & $11(3)$ & $37(10)$ & $100(3)$ \\
\hline Grand Total & & $100(3)$ \\
\hline
\end{tabular}

() indicated number of sample

Table 4: Microbiological analysis of the household's storage water samples of Barguna Pourashava.

A total of nine samples, one from each ward were collected form the entry point of the supply water to the user's house were analyzed for $E$. coli which represented the quality of the piped water. The analysis results are presented in Table 3. The result indicated that the supply line water in one wards has intermediate risk of microbiological contamination considering the health and the remaining have variable degrees of risk. Three household's storage samples were collected randomly from each of the 9 wards of the Pourashava for microbiological analysis and the total samples collected samples were 27 . The analysis results were categorized by considering the E. coli concentration per $100 \mathrm{ml}$; namely
0 for low risk, 1-10 medium risk, and 11-99 high risk and above 100 is very high risk. The analysis result indicated that $11 \%$ have intermediate risk, $37 \%$ have high risk and $52 \%$ have very high risk of considering the health (Table 4).

\section{Water quality in Faridpur Pourashava water supply system}

The analysis results of water samples collected from nine production well of the Faridpur Pourashava water supply system is presented in Table 5. The result indicated for high concentration of the arsenic, iron and $E$. coli in the production well's water. A total of nine samples, one 
Citation: Kormoker T, Proshad R, Khan MM (2017) Analysis of Water Quality in Urban Water Supply System of Bangladesh. J Environ Anal Toxicol 7: 492. doi: 10.4172/2161-0525.1000492

Page 4 of 5

\begin{tabular}{|c|c|c|c|c|c|c|c|c|c|c|c|}
\hline No & Particulars & Unit & $\begin{array}{c}\text { Goal } \\
\text { Chamot } 1\end{array}$ & $\begin{array}{c}\text { Goal } \\
\text { Chamot } 2\end{array}$ & $\begin{array}{c}\text { Goal } \\
\text { Chamot } 3\end{array}$ & $\begin{array}{c}\text { Goal } \\
\text { Chamot } 4\end{array}$ & Jhiltuli 1 & Jhiltuli 2 & Jhiltuli 3 & Jhiltuli 4 & Jhiltuli 5 \\
\hline 1 & Location & & In front gate & $\begin{array}{l}\text { Salim's } \\
\text { house }\end{array}$ & $\begin{array}{c}\text { Bishorgon } \\
\text { Ghat }\end{array}$ & Bus stand & Road side & $\begin{array}{l}\text { Moshiur's } \\
\text { house }\end{array}$ & Anis's house & $\begin{array}{c}\text { Behind filter } \\
\text { house }\end{array}$ & $\begin{array}{l}\text { Mizan's } \\
\text { house }\end{array}$ \\
\hline 2 & Source Type & & STW & STW & STW & STW & STW & STW & STW & STW & STW \\
\hline 3 & Depth & & 380 & 300 & 290 & 300 & 290 & 290 & 295 & 290 & 300 \\
\hline 4 & Color & & Reddish & Reddish & Reddish & Reddish & Light Reddish & Light Reddish & Light Reddish & $\begin{array}{l}\text { Light } \\
\text { Reddish }\end{array}$ & $\begin{array}{l}\text { Light } \\
\text { Reddish }\end{array}$ \\
\hline 5 & Odor & & Fishy Smell & Fishy Smell & Fishy Smell & Fishy Smell & Fishy Smell & Fishy Smell & Fishy Smell & Fishy Smell & Fishy Smell \\
\hline 6 & $\mathrm{pH}$ & & 7.50 & 7.09 & 7.42 & 7.18 & 7.24 & 7.44 & 7.34 & 7.26 & 7.16 \\
\hline 7 & ORP & $\mathrm{mV}$ & 150.1 & 155.4 & 148.4 & 168.7 & 53.9 & 102.3 & 20.6 & 58.8 & 22.4 \\
\hline 8 & Conductivity & $\mu \mathrm{s} / \mathrm{cm}$ & 1462 & 1693 & 1040 & 1091 & 1035 & 1019 & 852 & 894 & 440 \\
\hline 9 & Salinity & $\mathrm{mg} / \mathrm{l}$ & & & & & & & & & \\
\hline 10 & LOD & $\mathrm{mg} / \mathrm{l}$ & 6.99 & 7.28 & 6.85 & 7.47 & 4.24 & 4.77 & 3.07 & 4.74 & 7.56 \\
\hline 11 & Turbidity & NTU & 57.6 & 64.3 & 82.4 & 136.0 & 69.6 & 67.0 & 81.5 & 69.2 & 58.8 \\
\hline 12 & As & $\mathrm{mg} / \mathrm{l}$ & 170 & 235 & 225 & 135 & & & & & \\
\hline 13 & $\mathrm{Fe}$ & $\mathrm{mg} / \mathrm{l}$ & 6.8 & 8.9 & 14.6 & 11.6 & 6.3 & 4.1 & 3.2 & 2.6 & 2.45 \\
\hline 14 & $\mathrm{Mn}$ & $\mathrm{mg} / \mathrm{l}$ & 0.4 & 0.3 & 0.3 & 0.9 & 0 & 0 & 0.3 & 0.3 & 0.4 \\
\hline 15 & Nitrate & $\mathrm{mg} / \mathrm{l}$ & 0 & 0 & 0 & 0 & 0 & 0 & 0 & 0 & 0 \\
\hline 16 & E. coli & $/ 100 \mathrm{ml}$ & 30 & 25 & 31 & TNTC & 36 & 112 & 12 & 54 & 53 \\
\hline 17 & Other coli form & $/ 100 \mathrm{ml}$ & 280 & 37 & 192 & TNTC & 80 & 204 & 35 & 43 & 47 \\
\hline 18 & Total coli form & $/ 100 \mathrm{ml}$ & 310 & 62 & 223 & TNTC & 116 & 316 & 47 & 97 & 100 \\
\hline
\end{tabular}

TNTC: To numerous to count) in the source water

Table 5: Water quality analysis result of the production tube wells of Faridpur.

\begin{tabular}{|c|c|c|c|c|c|}
\hline \multirow{2}{*}{ Ward No } & \multicolumn{5}{|c|}{ Microbial Risk (HH's source water sample) } \\
\hline & Low & Intermediate & High & Very High & Grand Total \\
\hline Ward 1 & & 1 & & & 1 \\
\hline Ward 2 & & & 1 & & 1 \\
\hline Ward 3 & & 1 & & & 1 \\
\hline Ward 4 & & 1 & & & 1 \\
\hline Ward 5 & 1 & & & & 1 \\
\hline Ward 6 & 1 & & & & 1 \\
\hline Ward 7 & & & 1 & & 1 \\
\hline Ward 8 & & & & 1 & 1 \\
\hline Ward 9 & & & 1 & & 1 \\
\hline Grand Total & 2 & 3 & 3 & 1 & 9 \\
\hline
\end{tabular}

Table 6: Microbiological analysis of the household's source water samples of Faridpur Pourashava.

\begin{tabular}{|c|c|c|c|c|c|c|}
\hline \multirow{2}{*}{ Ward No } & \multirow{2}{*}{ Source } & \multicolumn{5}{|c|}{ Microbial Risk (HH's storage water sample) } \\
\hline & & Low & Intermediate & High & Very High & Grand Total \\
\hline Ward 1 & Intermediate & & & $100(3)$ & & $100(3)$ \\
\hline Ward 2 & High & & $33(1)$ & $67(2)$ & & $100(3)$ \\
\hline Ward 3 & Intermediate & & & $33(1)$ & $67(2)$ & $100(3)$ \\
\hline Ward 4 & Intermediate & & & $67(2)$ & $33(1)$ & $100(3)$ \\
\hline Ward 5 & Low & & & $67(2)$ & $33(1)$ & $100(3)$ \\
\hline Ward 6 & Low & & $33(1)$ & & $67(2)$ & $100(3)$ \\
\hline Ward 7 & High & & & & $100(3)$ & $100(3)$ \\
\hline Ward 8 & Very High & & & & $100(3)$ & $100(3)$ \\
\hline Ward 9 & High & & & $67(2)$ & $33(1)$ & $100(3)$ \\
\hline Grand Total & & & $7(2)$ & $44(12)$ & $48(13)$ & $100(27)$ \\
\hline
\end{tabular}

Table 7: Microbiological analysis of the household's storage water samples of Faridpur Pourashava.

from each ward were collected form the entry point of the supply water to the user's house were analyzed for $E$. coli which represented the quality of the piped water. The analysis results are presented in Table 6. The result indicated that the supply line water in two wards has low risk of microbiological contamination considering the health and the remaining have variable degrees of risk. The Table 7 represents the analysis result of $E$. coli of the household's storage water sample. The result indicated that $48 \%, 44 \%$ and $7 \%$ have very high risk, high risk and intermediate risk from the health point of view.

\section{Conclusion}

Urban water supply system in Bangladesh is not satisfactory because it possess human health risk. It is a threat to urban people as they suffer from different diseases due to drink these contaminated 
Citation: Kormoker T, Proshad R, Khan MM (2017) Analysis of Water Quality in Urban Water Supply System of Bangladesh. J Environ Anal Toxicol 7: 492. doi: 10.4172/2161-0525.1000492

Page 5 of 5

supply water in Bangladesh. There observe in both Barguna and Faridpur Pourashava that E. coli have a great negative impact on human health of Bangladeshi people. It causes very high health risk to urban people. Government should take necessary steps for reducing the risk of supply water contamination.

\section{Acknowledgements}

This works was supported by the Department of Public Health Engineering Bangladesh. Their help is sincerely acknowledged.

\section{References}

1. Kamal AM (2003) Attitude and opinion of the people regarding water supply: A case study of slum dwellers. Water and sanitation for cities. Dhaka: BIP and CUS.
2. Jayyousi $A$ (2001) Protection of the quality and supply of freshwater resources: Application of integrated approaches to the development. Management and Use of Water Resources, Localizing Agenda 21 in Palestine, pp: 161-205.

3. BBS (2007) Bangladesh Bureau of Statistics, Peoples Republic of Bangladesh, Dhaka, Bangladesh.

4. Rahman SMS, Jahan S (2003) Planning for a viable water supply system for Borisal City, Water and sanitation for Cities. World Habitat Day 2003 Souvenir, Bangladesh Institute of Planners (BIP) \& Center for Urban Studies (CUS), Dhaka, Bangladesh.

5. APHA (2003) Standard methods for the examination of water and wastewater 4th edn. American Public Health Association/America Water Works Association/ Water Environment Federation, Washington DC, USA. 